\title{
The Science and Trust Issue (After Covid 19)*
}

\author{
Covid 19 Sonrası Bilim ve Güven Problemi
}

\begin{abstract}
Ali ÖZTÜRK ${ }^{1}$
Makale Bilgisi/ Article Information

Geliş/ Received: 15.10 .2021

Kabul/ Accepted: 21.11.2021

Yayın/ Published:31.12.2021

\section{Araştırma makalesi/Research article} Doi: $10.47155 /$ mamusbbd. 1010083

\section{Kaynakça Bilgisi/ Citation Information}

Öztürk, Ali, (2019). The science and trust issue (after covid 19). Maarif Mektepleri International Journal of Social and Humanistic Sciences, 4(2), 8693. https://doi.org/10.47155/mamusbbd.1010083

Öztürk, Ali, (2019). Covid 19 sonrası bilim ve güven problemi. Maarif Mektepleri Uluslararası Sosyal ve Beşerî Bilimler Dergisi, 4(2), 86-93. https://doi.org/10.47155/mamusbbd.1010083

$\ddot{O} \mathbf{z}$

Baş döndüren bu modern dünyayı bilimsel bilgi sayesinde inşa ettik. Teknolojideki gelişmeler, yeni keşifler bilinmeyen birçok soru ve sorun bilim sayesinde açığa çıktı. Bilim sayesinde yeni bir dünya cenneti kurmaya ramak kaldı. Böyle inanlarımız çoktur. Özelikle doğrudan bilim felsefesiyle ilgilenmeyen birçok insan bu sözlere gönül rahatlığıyla kanabilir. Bu yaklaşımları eleştirenler de oldu. Bilim yeni bir killese icat ediyor diyenler, bilim bir kabile bilgisi gibi kendine özgü bir bilgidir, diyenler, bilim bir büyük yanılsamadır diyenler, bilim bizi felakete sürüklüyor diye haykıranlar hep oldu. Ama böyle düşünenler azdı ve onlar sıradan insana pek bir şey söylemiyordu. Şimdi bu pandemi ile işler biraz değişti. Modern dünya artık baş döndürmüyor, çünkü klasik insan öldü; nano-insan ise bu yeni-yapay dünyayı doğal bir dünya gibi görüyor. Yani insan alıştı, ama artık bilimi bir uğraş gibi görmek istiyor, başarılı-başarısız bir uğraş. Anlaşılan hakikat ışığı bilim bildiğimiz bir maraba uğraşına dönmeye hazırlanıyor. Şimdi pandemi de bu hakikate yardım etti, bilim zaten klasik inançlarımızı epeyce yormuştu. Peki, şimdi ne oldu? Şimdi bilim değil, yerine hezeyanlarımız metafizik üretecek, bilimse sıradan bir iş olacak öyle mi, bunu çeşitli parametrelerle tartışmaya çalışıyorum. Ola ki geleceği biraz daha fazla anlama şansımız olsun.
\end{abstract}

Anahtar Kelimeler: Bilim, Güven, İmgenin Epistemolojisi (İmajoloji), Kriz, Şüphe

\footnotetext{
*Bu makale 2021'de Uluslararası sempozyumda sunulmuş ve özeti yayınlanmıştır.

${ }^{1}$ Alanya Alaaddin Keykubat Üniversitesi, Eğitim Fakültesi, Psikolojik

Danışmanık ve Rehberlik Bölümü, Doç. Dr.
}

\section{通焦ajoloji@gmail.com \\ $0000-0002-7810-3152$}




\begin{abstract}
Covid 19 has radically shaken many things in our lives. Undoubtedly, belief in science has passed a huge test beyond our general believes. Most of the people have begun to apparently express their doubts on this matter. Indeed, the problem of trust in science is not particularly new but has a new level. However, given this change, our confidence in science needs to be reassessed. In essence, this study aims to address the problem of trust in science in light of these new developments. In this framework, the nature and limits of science will be discussed again. Differences between the legendary possibilities of science and its real possibilities will be questioned. With the promising possibilities of the discipline of "imajoloji" developed by us, the problem of scientific trust will be handled comparatively against the reality of covid 19 which we are facing in our times.
\end{abstract}

Keywords: Science, Trust, Epistemology of image (imajoloji/imagology), Crisis, Doubt.

\title{
Introduction
}

The relationship between humanity and faith or trust has been a very important issue. As a matter of fact, man has somehow lived constantly with various beliefs. In fact, for many reason, man by his very nature needs to believe something whatever that is. For instance, if we did not have any postulate (namely, we must believe in something as the basis of reasoning) we would have never done philosophy, made science, created literature, drew picture, developed technology and so on. Accordingly we could never have established civilization, city, society, and any human made-made things and activities. Therefore we may simply say that human partly consist of belief and trust (homo-faithus or homo religious) (Açıköz, 2020b, ss.223-229); because only in such a way that it is possible for him/her to do something. Long story short, in addition to many different reasons that should be mentioned, man by nature not only want to trust something but also need it in order to go on to produce anything.

Man who believes and trusts in a number of things is too numerous to count in every respect. The subject itself includes many multidimensional and multi-layered contexts. It can be handled from so many different points that religion, belief, culture, interdisciplinarity, individual, community, society, civilization, history, macro, micro and many other aspects etc. (Açıköz, 2020a). However I cannot mention all of these aspects here. Thus after touching more on the socio-psychological need of belief and trust, I would like to briefly touch on what kind of results the shaking of this situation led and what it means for the authority of science. Otherwise it would be impossible to get out of this complex issue.

In addition to many faith and trust relationships, people have felt the need to develop knowledge-based trust relationships. The knowledge-trust relationship has been institutionalized by philosophy and science (Hollis, 1986: 78). This trust audit, which has been going on for centuries, has passed through various tests and reached the present day. However, the acceptance of science as a type of knowledge that dominates the modern period provided it with a special opportunity. Although there were significant criticisms of science in the scientific and philosophical circles, ordinary person does not consider on this sufficiently. However, after Covid 19, there may have been some breaks in the approach of ordinary people towards the science. Because psychological approaches show us that there are serious convulsions in our basic belief and trust relationships after major traumas (Öztürk, 2020). 
On this occasion, in this study, the relationship between trust and science will be reexamined within the framework of this special case. Of course, this change is not only negative. Perhaps it will create an opportunity to reconsider the criticism of some opposing philosophers and scientists for centuries. Thus, we will have the chance to determine the healthy position that science deserves more accurately in a way that it is neither too much nor too little, as it should be. For man, the building of epistemology or knowledge has always been a problematic issue which has been arisen from the nature of man and knowledge. However in every era of man's history of knowledge or science both philosophers and scientists have been tried to overcome the historical problem (Öztürk, 2019). Historically this process covers the epistemological story of man in both sides of man and his knowledge which are about himself and the nature. In order to do these men apply either reductionist or holistic approaches in the names of philosophy, religion and particularly sciences (namely, natural and social sciences). Accordingly, herein we shall deal with the nature and outcomes of these approaches as to investigating nature of man and knowledge so that our aim will be to offer solutions to the problem.

I will face the problem as to several aspects in terms of a newly offered terminology, approach, method for presenting an imagistic sociology and its communities with respect to imagology ${ }^{2}$. In fact description, role and function of social science have steadily changed from early time to today. This historical fact suggests that like sociology which is not pure conjectural discipline, but its definition, role and function has changed according to periods, civilizations, schools, approaches and so on. Depending on these factors, sociology in particular and social science in general have also been reshaped and reconstructed, and therefore its concepts, methods and subjects have accordingly changed.

Accordingly, new era means new ideas, approach, method, definition, explanation, description and comment which naturally differ from the same items of the 19th era. Thus, we obviously need new concepts, paradigms, methods, and approaches etc. in order to take further step to examine the structure of social science as based on new realities. Indeed, there are many scientists who think this in many respects that some of these are simulation theory, fiction concept, post-modernist approaches, post-structure, imaginative realty, imagology and so on. Additionally we shall deal with current problems in terms of the frameworks of imagistic sociology and offer its basics so as to test imaginative communities and reforming it as well as discussing topics and issues have been arisen sofar in this particular community (Öztürk, 2016).

\section{A Brief Approach to the Importance of the Sense of Trust}

\footnotetext{
${ }^{2}$ Imagology; a new discipline that includes; image epistemology, cultural perceptions, communication, media, new media's, virtual society, social media and so on. In this context, we live in world of image and this age is further realized this fact. Therefore, I also re-systemized, re-conceptualized and re-established this situation so that I offer a "İmajoloji" in Turkish pronounce and spelling ("imagology" in English) and it includes ten chapters written by myself. Discipline of İmajoloji is a new offer about relationship between knowledge and human via epistemology of image. This epistemic model obtains reinterpreted social and political life. Certainly we find traces of İmajoloji, in Plato, Bacon, Adorno, Heidegger, Baudrillard, Foucault, Derrida, many Islamic Philosophers and so on. According to me the human being is created within a World of images for in this period life that an individual confronts in real life. However, it is a questionable situation because of impossibility of absolute realty for human. But we have been surrendered by reactions of image resources that include some realty. Thus human has never believed in this realty exactly. He has created alternative realities, alternative images, symbols and tools. More importantly we could manipulate facts according to our position, ideology, politic approach, civilization and so on. Briefly, I argue this conception framework around image epistemology and its reaction on social life. It also includes the epistemological debates about the future of western culture and philosophy (Öztürk; 2001).
} 
In general, trust is a vital two-sided concept that is needed more. It is central to interpersonal and is crucial wherever risk, uncertainty, or interdependence exist. These conditions flourish in many settings, and certainly exist in the relationship between knowledge. As conditions become more uncertain the need for trust grows (McKnight and Chervany, 2000).In short, it is not possible for us to do any work or make any decisions without this feeling.

First of all, belief, religion and similar values that are vital for human beings can be explained almost entirely in terms of trust. Therefore, humanity felt the need to produce values that would guarantee the feeling of trust. On the other hand, faith and trust did not always lead to an opportunity that has the same effect everywhere. However, it is not possible to talk about any type of relationship that is not based on faith and trust.

For this reason, humanity has connected its relations and productions to common agreement in various ways on which faith and trust will be based. Although this is not always based on the same principles everywhere, it is the case that it is somehow connected to a contract. It is clear, however, that most of the individual and societal changes arose out of the debates over this common contract (Ayer, 1969).

Sometimes this feeling is shaken for many reasons in particularly global disease like corona virus pandemic. Then either chaos happens or a new way is found to overcome. Sometimes such big changes can shake even our unexpected constants. As a matter of fact, about science, which has almost been accepted as the only reliable information in the world for nearly three centuries, grunts from ordinary people began to be heard. Thus, Columbia University also started a discussion on this general topic in 2020.The main question is: What could or will happen in this situation? Because as Sorokin said, "Nothing to be as they used to be". Now I shall try to understand the content and extent of this main question.

\section{A Brief Overview of Criticism of Science and Trust}

It is not easy at once to reply the question of what the science is at all. This situation can indeed change depending on many reasons by responding to the following questions: Is science the only thing? What is the nature of science? Are there general acceptances about science? Can we talk about very different sciences? These and hundreds of other questions complicate this answer since science has a monolithic symbol for the ordinary people.

The science which is that is reliable, correct and can work out all problems. Frankly, there was a very clear reason why people were so committed to science. Because, the success of the new world was thanks to science, in addition, the great mythological images of science developed over the last four centuries were very influential. Thus, a small group of people who strongly oppose science and a large western or westernizing society or societies that believes that science can solve any problem (Ayer, 1969; Erkan, 2019).

First of all, it should be noted that there is a vital relationship between science and trust. To violating the scientific rules defects the sense of trust in every respect. Since sense and practice of trust is very important issue for both the men of science and the life of ordinary people in responding to scientific issues (Hendriks and others: 2016).

\section{The New Role of Science and Its Periodic Images and Metaphysics}


We know that approaches to science are not static, and this fact is also valid its roles and images. In addition, the metaphysical assumptions of science show profound differences from period to period, apart from some approaches. At the beginning of the modern era, the belief that science would solve everything was widely accepted. Science was accepted as the only truth knowledge. It disgraced the value and validity of all information and knowledge that accepted by public. In short, experienced knowledge is superior, others are nonsense, that is, and science is a perfect religion (Brown, 1982).

Frankly, it had very strong evidence for this victory as well, because it created a new world based on technology. We would no longer need anything else. However, this situation did not fully comply with human nature, and things did not go as it wanted. So the aforementioned metaphysical role of science began to change. Indeed, skeptical approaches to science included deep considerations from ancient Greece to postmodern philosophy, but even these criticisms were not independent of this practice (Evangeliou, 1997; Şimşek, 2012).

Some religious and cultural circles have always maintained their doubts about science (Quinton, 1982). On the other hand, in fact, it is clear that many currents, starting with the sophists in philosophy, are in a clear attack on the authority of science. As for modern age, Kuhn's paradigm and Popper's falsifiability theory opened up a new avenue. This was later given a new face by the offensive insults of Feyerabend and others.

In summary,

a- Science is not independent of people and intention.

b- It is not independent of culture and civilization.

c- It is not free from interests and dirty accounts.

d- It is not free from time and conditions.

e- it has priorities

f- It depends on skills.

g- They have solid ideological baggage and so on (Öztürk, 2019).

As for postmodern age science obtained a new face that prioritizing their approaches to gender, increasing environmentally sensitive discourses, empowering marginal motivations, etc. acquired a fragmented metaphysical role tied to some moral orientations. While these limitations raise extremely important issues, they have also turned into a vicious circle that has almost taken the social sciences hostage.

In summary, the more subjects' science touches, the more narrowly it develops a metaphysical obsession. This causes its image to be damaged by large segments of society. I think that science should give up the rigid metaphysical cries (Ayer, 1964). This also undermines the wealth of his work. As a matter of fact, I am tired of reading studies that are quite numerous but tell the same tales.

\section{Conclusion}


Trust is a very basic feeling or emotion which has been expectedly based upon the rational ground. For this reason, people do not trust out of the blue and do not lose their faith out of the blue. Such a change develops for many reasons. Major traumas are one of the most important reasons that triggered this change. This latest global trauma has put direct science to the test. This is actually a good opportunity if we want science to function properly.

a- We must abandon mythological beliefs about science.

b- We must clearly identify the inadequacies and deficiencies of science.

c- We must clearly identify the negativities that are possible on and through science.

d- We must admit very clearly the limits of science.

e- We must openly decipher the political, ideological, and self-interested aspects of science.

f- We must stop using science as a tool against values and beliefs outside its borders.

After all, science is a human activity and is affected by human vulnerabilities just as much as any other factor. As Quine and Ullian (1978) correctly state with this awareness, we should use science as effectively as possible to develop solutions to problems. But without forgetting that our human and moral obligations are valid in science in the things we do wrong. However, while doing science, we should not forget that our human and moral obligations apply to the work we do since science which is not a self-evident thing.

I would like to conclude the article with a figurative statement: The world does not revolve around us, but the words revolve around our minds. Because the world is not a prisoner of our desires, maybe we are a prisoner of words. Because we cannot invade the world without knowing it, but here the dramatic truth suddenly emerges; the more you run behind the words, the more they catch and imprison you. So you think you're a king whereas you're a real slave.

\section{References}

Açıköz, H. M. (2020a). Theosophical essays (Cosmology, man and culture), Elis.

Aç1köz, H. M. (2020b). Ontological background of literature at the sample of the evolution of homo muslimus - I: theoretical frame and preliminaries. Anemon, Journal of Social Science of Muş Alparslan University, 8 (1) 223-229. http://dx.doi.org/10.18506/Anemon.578150

Ayer, A. J. (1964). Man as a subject for science. Nature, 203, 698. https://doi.org/10.1038/203698b0

Ayer, A. J. (1969). Metaphysics and common sense. Palgrave

Brown, J. R. (1982). The miracles in science. The Philosophical Quartely, 32 (128), 232-244.

Erkan, Ü. (2019). Lacan'da öznenin kurulumu ve ötekinin inşası psikanaliz ve oryantalizm, Turkish Studies, 14 (3), 1425-1440.

Evangeliou, C.C. (1997). The Hellenic philosophy: Between Europe, Asia and Africa. Global Publication, Binghamton University, New York.

Hendriks, F., Kienhues, D., \& Bromme, R. (2016). Trust in science and the science of trust. In B. Blöbaum (Ed.), Trust and communication in a digitized world: Models and concepts of trust research (pp. 143-159). Springer International Publishing. https://doi.org/10.1007/978-3-319-28059-2_8

Hollis, M. (1986). Invitation to Philosophy. Blackwell. 
Mcknight, D. H., \& Chervany, N.L. (2000). What is trust? A conceptual analysis and an interdisciplinary model. In Proceedings of the AMCIS Americas Conference on Information Systems (pp.827-833). Long Beach, California: AMCIS. http://aisel.aisnet.org/amcis2000/382

Öztürk, Ali, (2019). Imajoloji (Yenibirdisiplindenemesi). 3. Basım. Elis Yayınları,

Öztürk, A. (2020). Siber küresel: Nano-İnsan, sanalite toplum ve diji-topluluklar (Qu-Post pandemi sonras1 dünya). Çocuk ve Medeniyet, 5 (9), 55-71. https://dergipark.org.tr/tr/pub/cm/issue/57383/813174

Şimşek, R. (2012). Liberteryen ve komüniteryen çokkültürcülük dikotomisi, IIB International Refereed Academic Social Sciences Journal, 3 (7), 92-107.

Quine, W. V., \& Ullian, J. S. (1978). The web of belief. McGraw-Hill Humanities/Social Sciences/Languages.

Quinton, A. (1982). Thoughts and thinkers. Springer International Publishing.

Https://Incite.Columbia.Edu/Mellon-Sawyer-Seminar-On-Trust-And-Mistrust-Of-Science-AndExperts 8.10 2021. 